\title{
ASPECTOS RELEVANTES DAS TUTELAS PROVISÓRIAS DE URGÊNCIA NOS SISTEMAS PROCESSUAIS BRASILEIRO E PORTUGUÊS ${ }^{1}$
}

\section{RELEVANT ASPECTS OF INTERIM INJUNCTIONS IN THE BRAZILIAN AND PORTUGUESE PROCEDURAL SYSTEMS}

Paulo Guilherme Mazini Mestre em direito das relações sociais pela UFPR. Doutorando em direito processual civil pela USP. Professor de direito processual civil na graduação da Unibrasil - Curitiba e na pósgraduação da ABDCONS- Curitiba. Juiz de Direito Substituto em Curitiba. Curitiba/PR. E-mail: pgmazini@uol.com.br.

RESUMO: A tutela provisória ainda se apresenta como um dos temas mais discutidos no processo civil, especialmente após a vigência do novo Código de Processo Civil brasileiro, que passou a ser aplicado no ano de 2016. Algumas mudanças relevantes foram propostas com o novo diploma legal, as quais tiveram por objetivo, sobretudo, a unificação do regime das tutelas de urgência e a inclusão de uma nova modalidade de estabilização das decisões a ser observada nas tutelas satisfativas ajuizadas em caráter antecedente. Em Portugal, o Código de Processo Civil em vigor desde o ano de 2013, apesar de suas distinções e da convivência do regime de cautelares típicas e atípicas, previu um modelo interessante de resolução sumária de conflitos denominado inversão do contencioso, além de apresentar uma modalidade de tutela autoexauriente com nítida aproximação das tutelas inibitórias do direito brasileiro. Pretende-se assim, com o presente artigo, desenvolver, sob a perspectiva do direito comparado, um estudo com a finalidade de analisar os principais pontos de vista a respeito das tutelas sumárias nos sistemas brasileiro e português.

PALAVRAS-CHAVE: Tutela de Urgência. Pontos Relevantes. Direito Comparado. Brasil. Portugal. Procedimento.

\footnotetext{
${ }^{1}$ Artigo recebido em 05/05/2021 e aprovado em 01/07/2021.
} 
ABSTRACT: Interim injunction is still one of the most discussed issues in civil procedure, especially after the new Brazilian Code of Civil Procedure, which came into force in 2016. Some relevant changes were proposed by the new set of laws, which aimed, above all, to unify the system of injunctive relief and the inclusion of a new category of decisions stabilization to be observed in the injunctions filed in advance. In Portugal, the Code of Civil Procedure in force since 2013, despite its distinctions and the coexistence of a typical and atypical injunctions regime, envisioned an interesting model of summary resolution of conflicts called reversal of litigation, in addition to presenting a self-exhaustive type of injunctions with a clear similarity with the injunctions in the Brazilian law. Therefore, the aim of this article is to develop, from the perspective of comparative law, a study which purpose is analyzing the main points of view regarding summary injunctions both in the Brazilian and Portuguese systems.

KEYWORDS: Interim Injunction. Relevant Aspects. Comparative Law. Brazil. Portugal. Procedure.

Sumário: 1. A tutela provisória no Brasil de acordo com o CPC/2015. 2. A unificação do regime. 3. Análise crítica da terminologia tutela provisória. 4. A classificação das tutelas de urgência no direito brasileiro e quanto ao momento de sua concessão. 5. A estabilização da tutela antecipada antecedente. 6. As tutelas provisórias no sistema português e a influência de Piero Calamandrei. 7. Funcionalidade das cautelares no sistema português: 7.1 Garantia de Direitos. 7.2 Regulação provisória de situação jurídica. 7.3 Antecipação de efeitos jurídicos. 8. As cautelares típicas. 8.1 Restituição provisória de posse. 8.2 Suspensão de deliberações sociais e da assembleia de condôminos. 8.3 Alimentos provisórios. 8.4 Arbitramento de reparação provisória. 8.5 Arresto. 8.6 Embargo de obra nova. 8.7 Arrolamento. 9. As cautelares atípicas e as suas linhas gerais. 10. A inversão do contencioso e o rompimento do dogma da instrumentalidade. 11. Tutelas autossatisfativas e tutelas de urgência stricto sensu. 12. Considerações finais. 13. Referências bibliográficas.

\section{A tutela provisória no Brasil de acordo com o CPC/2015}


O CPC brasileiro atualmente em vigor, realizou importantes inovações quanto ao tema tutelas provisórias, o que resultou, inclusive, num procedimento mais simplificado e, a priori, apartado dos debates que envolveram a natureza das medidas de urgência que salvaguardavam o direito das partes, os quais estavam relacionados com a vocação conservativa ou satisfativa das tutelas de urgência.

E a rigor, sob a égide do CPC revogado, para prevenir que os entendimentos de juízes distintos não comprometessem a tutela do direito material que reclamava a concessão de uma medida de urgência, foi introduzido um dispositivo legal que consagrou o Princípio da Fungibilidade das Tutelas de Urgência ${ }^{2}$, de modo que, uma vez pleiteada uma tutela cautelar como tutela antecipada, o juiz estava autorizado a concedê-la com fundamento no referido princípio, o que rendia ensejo, inclusive, para que a tutela antecipatória fosse deferida mesmo que o requerimento tivesse sido realizado no bojo de uma medida cautelar. De fato, razão não havia para que a fungibilidade operasse apenas a partir de um lado, qual seja, das cautelares requeridas como tutelas antecipadas, pois do contrário, o próprio postulado constitucional de acesso à jurisdição que assegura a prestação adequada no seu tempo, estaria subvertido por um formalismo estéril e desprovido de maior racionalidade. ${ }^{3}$

De qualquer forma, é certo que até a introdução do princípio da fungibilidade ora em comento, o que ocorreu efetivamente com a lei n. 10.444/02, algumas situações na praxe forense geraram perplexidade, diante do indeferimento de tutelas antecipadas lastreadas no entendimento do juiz de que o pleito tinha natureza acautelatória, ou vice-versa.

Este cenário modificou-se com o CPC/2015, notadamente porque não se vislumbra mais a autonomia estrutural antes concebida para as tutelas cautelares, que, disciplinadas em livro próprio, eram processadas em autos próprios que seguiam apensados aos da ação principal, o que, diga-se de passagem, mostrava-se contraproducente e afrontava o princípio da economia processual, já que o autor de uma ação cautelar, preparatória ou incidental, era

\footnotetext{
${ }^{2}$ A previsão contida no art. $273, \S 7^{\circ}$ do CPC/73, estabelecia que, se o autor, a título de antecipação de tutela, requerer providência de natureza cautelar, poderá o juiz, quando presentes os respectivos pressupostos, deferir a medida cautelar em caráter incidental do processo ajuizado.

${ }^{3}$ Conforme bem observou Cândido Dinamarco: Não há fungibilidade em mão única de direção. Já é geralmente aceito, diante disso, que o novo dispositivo autoriza o juiz, amplamente, a receber qualquer pedido de tutela urgente, enquadrando-o na categoria que entender adequada, ainda que o demandante haja errado ao qualificar o que é cautelar como antecipação, ou o que é antecipação, como cautelar (DINAMARCO, C. R. Nova Era do Processo Civil. 4. ed. São Paulo: Malheiros, 2013. p. 71).
} 
compelido a recolher custas processuais sem prejuízo do recolhimento que realizava na demanda principal.

Assim, apenas para propor uma medida cautelar que poderia muito bem ser acomodada num tópico da petição inicial da ação principal, o autor era obrigado a apresentar uma demanda autônoma e recolher as custas processuais correspondentes, o que tornava o procedimento cercado de um formalismo inconsistente que em nada contribuía para uma gestão racional do processo.

A partir da vigência do CPC/2015 esta realidade modificou-se, na medida em que a tutela cautelar perdeu a sua autonomia estrutural, deixando assim, de ser aforada em autos próprios e passando a ser requerida na própria petição inicial.

Dessa forma, proposta a tutela cautelar em caráter antecedente e deferida a medida respectiva, cumpre ao autor aditar a petição inicial no prazo de trinta dias contados da efetivação da liminar, com a apresentação do pedido de tutela final e a complementação da causa de pedir, tudo nos mesmos autos e sem a necessidade de recolhimento de novas custas processuais. E na hipótese de a tutela cautelar ser requerida juntamente com o pedido de tutela final ou mesmo no curso do processo, o seu requerimento será realizado em tópico da petição inicial ou em simples petição apresentada incidentalmente nos autos, ou seja, durante o trâmite processual.

Com relação à tutela de urgência antecipada, por outra via, a par da possibilidade de ser requerida em caráter antecedente ou incidente, assim como ocorre com as tutelas cautelares, a previsão de sua estabilização foi uma inovação importante no regime das tutelas provisórias.

É relevante observar, de início, que apenas as tutelas antecipadas requeridas em caráter antecedente estão submetidas à estabilização. Quanto às tutelas antecipadas incidentalmente requeridas a estabilização não se aplica, até mesmo porque, conforme será melhor explicitado adiante, em tais casos, presume-se que as partes pretendam discutir a matéria controvertida em cognição exauriente, o que, a nosso aviso, mostra-se incompatível com o regime da estabilização.

\section{A unificação do regime}


Portanto, no sistema processual brasileiro atual, é possível inferir-se que houve, de certo modo, uma unificação do regime das tutelas provisórias de urgência, especialmente porque a sua disciplina foi, essencialmente, condensada num único dispositivo legal que estabeleceu os requisitos para a sua concessão. É inegável por outro lado, que a unificação referida não significa inexistir qualquer traço distintivo entre as modalidades de tutelas provisórias de urgência. De fato, embora os requisitos para a concessão das medidas tenham sido agrupados no dispositivo inserto no art. 300 do CPC, é indiscutível que historicamente, sobretudo após a reforma processual da lei n. 8.952/94, que introduziu as tutelas sumárias satisfativas no Código revogado, subsiste a autonomia funcional e diferenças substanciais entre as duas modalidades de tutelas de urgência. ${ }^{4}$

Neste sentido, não se afigura possível sustentar que houve uma unificação de regimes, diante das funções desempenhadas por tais modalidades de tutelas de urgência como instrumentos processuais. A cautelaridade, como meio vocacionado à conservação de direitos, não se confunde com a satisfatividade, que é inerente à tutela antecipada e que permite a realização imediata do direito material que somente seria concretizado num momento processual posterior à sentença de mérito.

Até mesmo alguma distinção entre as duas categorias de tutelas de urgência pode ser identificada no CPC, nada obstante a simplificação proposta através de sua previsão num único dispositivo legal, o que poderia sugerir, numa análise açodada, uma unificação de regime irrestrita, inclusive conceitual.

Por ilustração, o próprio art. $300, \S 3^{\circ}$, do CPC, apresenta um traço distintivo entre as duas modalidades de tutela de urgência, ao mencionar que a tutela antecipada não deve ser deferida diante do risco de irreversibilidade do provimento. Embora esta previsão deva ser analisada com temperamentos, à luz do princípio constitucional de acesso à jurisdição que impõe a prestação de uma tutela jurisdicional tempestiva, efetiva e adequada, independente da sua irreversibilidade, é inquestionável que o próprio Código estabeleceu uma diferenciação entre as duas modalidades de tutelas de urgência, o que teria por condão

\footnotetext{
${ }^{4}$ Assim, se afirmarmos que a tutela cautelar pode realizar o próprio direito (por exemplo, a pretensão aos alimentos), estaremos incidindo em contradição, pois uma vez realizado o direito material nada mais resta para ser assegurado. Ou seja, quando o direito é satisfeito nada é assegurado e nenhuma função cautelar é cumprida (MARINONI, L. G. A Antecipação da Tutela. 8. ed. São Paulo: Malheiros, 2004, p. 128).
} 
afastar, sobretudo no seu aspecto funcional, a tese de que houve uma verdadeira unificação do regime das tutelas de urgência.

\section{Análise crítica da terminologia tutela provisória}

O Código de Processo Civil brasileiro adotou a denominação tutela provisória como um gênero que é abrangido pelas tutelas de urgência e da evidência. A provisoriedade designada, a rigor, contrapõe-se à tutela definitiva que será obtida na conclusão do trâmite procedimental, com a prolação da sentença de mérito apta à outorga da tutela final.

A questão que exsurge a respeito, há muito tempo aliás, relaciona-se à terminologia utilizada para designar uma tutela que mantém a sua provisoriedade enquanto a tutela final não é concedida. De fato, a ideia transmitida pelo conceito adotado pode muito bem sugerir que a tutela provisória perdura até a concessão da tutela definitiva, o que coincide com o momento da entrega da prestação jurisdicional através da sentença de mérito.

Deve ser observado, no entanto, que a outorga da tutela definitiva nem sempre tem por corolário o término de vigência e a substituição da tutela provisória que foi deferida liminarmente. $\mathrm{Na}$ verdade, as tutelas provisórias e definitivas podem coexistir, e, inclusive, esta perspectiva é a que mais se ajusta com o direito fundamental de acesso à jurisdição, notadamente para que a sua prestação seja efetiva e oportuna quanto ao seu tempo. Isto porque, a função relevante que as tutelas de urgência desempenham no processo impõe que mesmo após a prolação da sentença de mérito, elas continuem atuando para que o direito do autor seja resguardado ou concretizado desde logo, antes do desfecho dos trâmites recursais. Inclusive, $\mathrm{o}$ art. 1.012, $\S 1^{\circ}, \mathrm{V}$ do $\mathrm{CPC}$, excepciona o recebimento do recurso de apelação no seu duplo efeito, nas hipóteses em que a tutela provisória é deferida ou confirmada na sentença de mérito, o que assegura a sua imediata executoriedade, ainda que em caráter não definitivo.

Assim, apenas para exemplificar, o julgamento do mérito da demanda que, em tese, representaria a substituição da tutela provisória pela tutela final, na verdade, não significa um marco temporal que põe termo à vigência da tutela provisória. Primeiro, porque, em se tratando de uma tutela provisória satisfativa, ela cumpre uma função importantíssima, 
mesmo que seja deferida na própria sentença, pois permite que o direito do autor seja imediatamente realizado independente da interposição de recurso pelo réu.

Neste ponto, a concessão da tutela antecipatória ou a sua confirmação na sentença, tem o condão de neutralizar o duplo efeito de um eventual recurso de apelação. Trata-se de um exemplo claro de que a tutela provisória não tem o seu prazo de duração restringido até a concessão da tutela final.

No tocante à tutela cautelar, talvez a situação seja ainda mais evidente, pois simplesmente, a sua vigência sequer poderia estar relacionada com o momento de outorga da tutela final que ocorre com a sentença de mérito. Ora, basta imaginar a situação de um arresto cautelar deferido como garantia de um futuro cumprimento de sentença numa demanda de cobrança. Não restam dúvidas em tal hipótese, que nem a sentença de mérito e nem mesmo o trânsito em julgado respectivo terão o condão de afastar o arresto enquanto o provimento cautelar não for convertido em penhora ou, eventualmente, enquanto o devedor não satisfazer voluntariamente o crédito reconhecido.

Portanto, a despeito do debate doutrinário ser bastante antigo quanto ao tema, parece que, de fato, a denominação de tutela temporária seria semanticamente mais apropriada para conceituar as tutelas sumárias não definitivas que se prestam tanto a satisfazer quanto a conservar direitos. $^{5}$

\section{A classificação das tutelas de urgência no direito brasileiro e quanto ao momento de sua concessão}

As tutelas de urgência no processo civil brasileiro, para melhor compreensão e sistematização, podem ser classificadas, conforme a sua funcionalidade dirigida à

\footnotetext{
${ }^{5}$ A crítica já era feita por Ovídio Baptista da Silva, que assim sustentava: CALAMANDREI não contrapõe a cautelaridade à satisfatividade, e sim à definitividade. Para ele, o elemento que distingue as duas categorias é a circunstância de ser a medida cautelar provisória e, como tal, oposta às providências definitivas. Para nós, ao contrário, as medidas cautelares devem ser temporárias e não provisórias, de modo a atender às seguintes exigências: a) Não deverá ter sua duração determinada pela emanação de uma providência definitiva que as substitua, mas haverão de durar enquanto dure o estado perigoso, e não mais! Como disse corretamente EGAS MONIZ DE ARAGÃO (ob.cit., n. 57, p. 49), o limite para as medidas cautelares é tal que deve ser sempre possível desfazê-las quando aquele que as obteve for vencido na ação principal. (SILVA, O. A. B. Curso de Processo Civil: Processo Cautelar. 3. ed. São Paulo, 2000. v.3.).
} 
conservação ou satisfação de direitos em: i- tutela de urgência cautelar; ii- tutela de urgência antecipada.

E com relação ao momento de sua concessão, vale dizer, se antes da apresentação ou complementação do pedido de tutela final, ou se durante o curso do trâmite processual, as tutelas de urgência são classificadas em: i- tutela de urgência cautelar antecedente e tutela de urgência cautelar incidente; ii- tutela de urgência antecipada antecedente e tutela de urgência antecipada incidente.

\section{A estabilização da tutela antecipada antecedente}

Consoante já mencionado prefacialmente, o CPC brasileiro em vigor inovou ao disciplinar o regime de estabilização da tutela satisfativa requerida em caráter antecedente. O regime em apreço, influenciado pelo processo civil italiano e francês, propõe que se a urgência de uma tutela satisfativa emergir simultaneamente ao ajuizamento da demanda, o autor poderá formular apenas o pedido de tutela antecipada com a referência ao pedido de tutela final e uma breve exposição da causa de pedir.

Dessa forma, deferida a tutela satisfativa em caráter antecedente, caberá ao réu interpor o recurso cabível que, em face da previsão do art. 1.015, I do CPC, será o recurso de agravo no prazo quinzenal. Em não sendo interposto o recurso, a tutela satisfativa estabiliza-se, cabendo às partes, caso pretendam revisar o seu conteúdo, propor a demanda de cognição exauriente em até dois anos, sob pena da decisão sumária respectiva tornar-se imutável.

Não se pretende nesta seara discutir a natureza da estabilidade após o decurso do prazo bienal, eis que este não é o propósito do presente ensaio. Entretanto, algumas breves observações quanto ao tema que, a nosso sentir, consiste num dos debates doutrinários mais polêmicos do CPC, merecem ser ventiladas.

Em primeiro lugar, deve ser destacado que apenas as tutelas satisfativas que são propostas em caráter antecedente estão submetidas ao regime da estabilização. Isto é o que pode ser inferido da interpretação sistemática dos dispositivos insertos no capítulo II do Título II do CPC. Ora, não há justificativa para adotar o regime da estabilização se o autor apresenta uma petição inicial completa, na qual deduz os pedidos de tutela provisória e tutela 
final e menciona, a par disso, a causa de pedir com todos os seus fatos e fundamentos de relevo. Nesta hipótese, parece claro que ele pretende que o mérito da demanda seja apreciado mediante cognição exauriente.

Outro ponto de destaque é a forma de irresignação do réu para evitar a estabilização da tutela satisfativa. Apesar de discussões doutrinárias a respeito, as quais, inclusive, pareciam render-se ao argumento de que qualquer insurgência do réu seria suficiente para afastar a estabilização, é digno de registro uma recente decisão emanada do Superior Tribunal de Justiça, sinalizando no sentido de que apenas o recurso de agravo impede a estabilização, não bastando para tanto, a apresentação da contestação. ${ }^{6}$

O último ponto que mencionamos nesta síntese do novel regime introduzido pelo CPC brasileiro é o seu confronto com o interessante regime da inversão do contencioso português, especialmente, no que tange à estabilidade das decisões.

Os dois regimes, ao que tudo indica, serviram-se das mesmas matrizes do direito comparado, e, nada obstante as distinções procedimentais de cada qual, conforme será abordado neste trabalho, a tutela de urgência submetida ao regime de inversão do contencioso parece submeter-se à imunização pela coisa julgada material (ou caso julgado material em Portugal), ao contrário do regime da estabilização da tutela satisfativa antecedente que, pelo menos numa interpretação literal do art. $304, \S 6^{\circ}$ do $\mathrm{CPC}$, não pode ser acobertado por esta estabilidade máxima.

\section{As tutelas provisórias no sistema português e a influência de Piero Calamandrei}

Inicialmente, deve ser destacado que as tutelas provisórias no processo civil português apresentam um modelo fortemente influenciado pela doutrina de Piero Calamandrei, como aliás, ocorreu no direito brasileiro, embora a reforma materializada através da lei n.8.952/94 tenha realizado a distinção entre as tutelas cautelares e satisfativas, que passaram a integrar uma modalidade autônoma de tutelas matizadas pela urgência. ${ }^{7}$

\footnotetext{
${ }^{6}$ Resp 1797365 / RS, Primeira Turma, Rel. Ministro Sérgio Kukina.

${ }^{7}$ Conforme salientou o Prof. Dinamarco: Influenciada pela lição prestigiosíssima de Calamandrei, a doutrina brasileira não se esmerava em levantar essa questão, sendo praticamente pacífica a crença na natureza cautelar dessas medidas, até quando chegou a primeira Reforma, com sua proposta de um novo conceito, ou de uma nova categoria jurídico-processual, que é a tutela antecipada (DINAMARCO, C. R. Nova Era do Processo Civil. 4. ed. São Paulo: Malheiros, 2013. p. 62).
} 
No sistema português, no entanto, sentiu-se a forte inspiração das ideias de Calamandrei, inclusive porque não se propôs uma classificação das tutelas antecipadas como categoria autônoma e distinta das tutelas cautelares. Prevaleceu assim, a natureza acautelatória de todas as medidas fundadas na urgência a partir dos critérios do pericolo di frutuositá e pericolo di tardivitá propostos por Calamandrei.

A primeira hipótese, refere-se ao risco de que o direito acautelado possa perecer e, dessa forma, seja difícil ou improvável a sua realização num momento futuro, caso a medida não seja imediatamente deferida. Trata-se de uma funcionalidade da tutela cautelar voltada a assegurar a eficácia do provimento principal, ou, em outras palavras, permitir que o direito material representado pelo provimento principal seja concretizado, conforme é o exemplo do arresto cautelar que resguarda a futura execução de um crédito.

A segunda hipótese, por seu turno, tem por escopo a imediata satisfação do direito pretendido pelo autor, porquanto a não concessão da medida prontamente poderia tornar-lhe inútil, o que justifica a necessidade de sua imediata realização. É o exemplo clássico da prestação de alimentos, imprescindível para a subsistência do autor durante o trâmite processual.

Calamandrei estabeleceu uma classificação das modalidades de cautelares em quatro grupos, quais sejam: i- produção antecipada de provas; ii- asseguração de uma futura execução; iii- cautelares antecipatórias; iv- caução que se presta como contracautelas judiciais. Assim, de acordo com a classificação apresentada por Calamandrei, as medidas cautelares antecipatórias vocacionadas a prevenir o pericolo di tardivitá abrangeriam, conforme bem observou Alcides Munhoz da Cunha, tanto a regulação provisória de uma situação jurídica quanto a própria antecipação do mérito de uma tutela final. ${ }^{8}$

\section{Funcionalidade das cautelares no sistema português}

\footnotetext{
${ }^{8} \mathrm{O}$ terceiro grupo de medidas cautelares abrangeria as providências antecipatórias, que importam em regulação provisória ou decisão antecipada do mérito ( satisfação provisória e antecipada) sobre uma relação que oportunamente deverá ser objeto de decisão definitiva no processo, cuja antecipação se realiza para afastar situação de perigo de dano irreparável ao interesse da parte requerente, em face do periculum in mora, isto é, em face do tempo demandado para a emanação do provimento definitivo. (CUNHA, A. A. M. Comentários ao Código de Processo Civil. São Paulo: Editora Revista dos Tribunais, 2001. v. 11. p. 111-2).
} 
No sistema português, a rigor, as tutelas cautelares típicas são reunidas em três grupos de acordo com a função desempenhada por cada qual. Assim, de acordo com o CPC português, as medidas cautelares são predispostas à: i- garantia de direitos; ii- regulação provisória de uma situação jurídica; iii- satisfação imediata do direito material.

\subsection{Garantia de Direitos}

A garantia de um direito que será discutido numa demanda principal é uma função tipicamente conservativa que se coaduna, a nosso aviso, com a verdadeira vocação da tutela cautelar como instrumento processual destinado à salvaguarda de direitos que correm o risco de perecimento no curso do debate suscitado numa demanda principal ou, no caso do sistema brasileiro, até que seja equacionada a controvérsia em cognição exauriente.

Esta classificação coincide, aliás, com a finalidade de assegurar uma execução futura, conforme doutrina clássica de Calamandrei, que é calcada justamente na imposição de que a medida seja concedida para prevenir o risco derivado da ineficácia de um provimento final, o que poderia ocorrer se, por exemplo, o requerido desse outro destino ao seu patrimônio para furtar-se ao cumprimento de uma obrigação certificada na sentença, ou mesmo se a permanência com uma das partes do bem que é objeto de discussão numa demanda principal, durante o seu trâmite, pudesse resultar na sua ocultação ou destruição, o que justifica a medida conservativa para a sua preservação até que seja ultimado o julgamento respectivo.

Ingressam na presente classificação funcional, as cautelares especificadas de arresto e arrolamento de bens previstas nos arts. 391 e 403 do CPC luso.

\subsection{Regulação provisória de situação jurídica.}

As providências cautelares voltadas à regulação provisória de situação jurídica, estão relacionadas funcionalmente à disciplina momentânea ou transitória de uma determinada relação jurídica submetida a litígio até a sua definição na demanda principal. Ao que tudo indica, a sua finalidade está muito mais permeada pela necessidade de prevenir outros 
conflitos ou prejuízos decorrentes da relação jurídica primitiva do que, a rigor, prestar-se como medida conservativa de direitos. ${ }^{9}$

Integram o enquadramento proposto nesta classificação, as medidas cautelares específicas de restituição provisória na posse, suspensão de deliberações sociais e embargo de obra nova, previstas, respectivamente, nos artigos 377, 380 e 397 do CPC português. É interessante pontuar que, apesar de se tratarem de cautelares que se ajustam num rol que tem por finalidade a regulação provisória de uma situação jurídica, é indiscutível que os provimentos encerram um caráter antecipatório da decisão de mérito.

Ora, ao restituir a posse a quem alega ter sofrido violação no seu direito, a decisão não está, a nosso aviso, apenas disciplinando o fato que resultou no litígio, mas, sem dúvida, antecipando o provimento que seria deferido na tutela final. Idêntico raciocínio aplica-se ao embargo de obra nova, já que a tutela final a ser deferida na sentença volta-se justamente a impedir que uma obra irregular seja levada adiante. Em síntese, o provimento deferido na tutela provisória é satisfativo, coincide, mesmo que parcialmente, com o conteúdo da tutela final e, consequentemente, tem aptidão para antecipar integralmente os efeitos da decisão de mérito, em que pese ter sido classificado como medida cautelar de regulação provisória, conforme já referido.

\subsection{Antecipação de efeitos jurídicos}

O terceiro grupo que integra a classificação das medidas típicas no sistema lusitano é pertinente às tutelas cautelares que permitem a antecipação de efeitos jurídicos. Tratam-se das cautelares satisfativas que se destinam a realizar, de plano, o direito material que será postulado na demanda principal. Coerentemente à funcionalidade das cautelares, segundo a doutrina de Calamandrei, as tutelas cautelares satisfativas são vocacionadas a combater o risco de um provimento tardio ou pericolo di tardivitá, o que resultaria na inutilidade da tutela final se não houvesse a sua concessão imediata.

\footnotetext{
${ }^{9}$ Por conseguinte, as providências cautelares de regulação provisória não se destinam propriamente a garantir um determinado direito, mas antes a evitar a ocorrência de prejuízos significativos ou a prevenir uma violência iminente ou outras razões consideradas necessárias. (GONÇALVES, M. C. Providências Cautelares. 3. ed. Coimbra, Portugal: Almedina, 2017).
} 
Assim, de acordo com esta premissa, o deferimento da prestação dos alimentos apenas na sentença resultaria na inutilidade de tal provimento, seja porque o autor já teria, nesta hipótese, obtido por outros meios os recursos necessários para a sua subsistência, ou então, atingido o estado de penúria que a concessão da tutela cautelar teria por escopo evitar.

No sistema português, a cautelar de alimentos provisórios e o arbitramento de reparação provisória amoldam-se precisamente nesta classificação, na medida em que permitem a imediata realização do direito de natureza alimentar, o qual somente seria materializado na sentença que condenasse o alimentante ou o causador do dano ao pagamento da prestação respectiva na demanda principal a ser aforada no prazo legal. ${ }^{10}$

\section{As cautelares típicas}

O sistema de tutelas provisórias de urgência disciplinado no CPC português, assegura a coexistência das cautelares especificadas ou típicas com as cautelares não especificadas ou atípicas. A única ressalva legal refere-se à inviabilidade de utilizar-se das tutelas cautelares atípicas em substituição às tutelas especificadas, quando os requisitos para a concessão destas últimas não se fizerem presentes. ${ }^{11}$

As cautelares especificadas foram contempladas no CPC lusitano em oito modalidades que se enquadram nas categorias já mencionadas nos tópicos 7.1 a 7.3 supra, de acordo com a sua funcionalidade.

\subsection{Restituição provisória de posse}

\footnotetext{
${ }^{10}$ Nestas medidas cautelares há sempre uma antecipação dos efeitos materiais da sentença final a ser proferida na acção principal, em caso de procedência. No entanto, mesmo nestes casos, as referidas medidas não perdem a sua natureza de provisoriedade. (CASTANHEIRA, J. M. C. As Providências Cautelares e os Requisitos para o seu Decretamento - Confronto entre o Processo Administrativo e o Processo Civil. Dissertação (Mestrado em Direito Administrativo) - Faculdade de Direito, Universidade de Coimbra. Coimbra, Portugal, 2018. Disponível em: estudogeral.uc.pt/bitstream/10316/86628/1/Tese\%20Joana\%20Castanheira.pdf. Acesso em: 30/11/2019.

${ }^{11}$ De todo o modo, o procedimento cautelar comum não pode ser utilizado como uma via alternativa para todas aquelas situações que não sejam tuteláveis pelas providências cautelares especificadas por faltar algum dos requisitos de que dependa a concessão da providência. (GONÇALVES, M. C. Providências cautelares. 3. ed. Coimbra: Almedina, 2017).
} 
A restituição provisória na posse é uma medida cautelar predisposta à regulação provisória de uma situação jurídica, apesar de insistirmos que o seu conteúdo é nitidamente antecipatório, diante da perspectiva de realização imediata do direito que somente seria efetivado numa sentença de mérito. E a bem da verdade, a tutela de reintegração na posse mais se assemelha à tutela fundada na evidência do direito, porquanto o periculum in mora, no mais das vezes, não se faz presente para o deferimento da medida.

E com efeito, a despeito das particularidades do sistema português, notadamente quando estamos diante de posse velha, ou seja, com prazo superior a ano e dia ${ }^{12}$, embora a proteção possessória seja assegurada ao legítimo possuidor, não há como sustentar-se pela presença do elemento urgência, o que permite inferir que a tutela cautelar in casu, assemelhase à tutela da evidência do direito brasileiro, modalidade de tutela provisória que não encontra correspondente no sistema lusitano.

\subsection{Suspensão de deliberações sociais e da assembleia de condôminos}

Esta medida cautelar, também classificada como regulatória de situações provisórias, tem lugar nas hipóteses em que as associações ou sociedades tomarem deliberações que, na visão de um ou mais sócios, é contrária à lei, estatutos ou ao contrato social. O prazo é peremptório, de dez dias contados da data em que a assembleia foi realizada ou da data em que o autor tiver conhecimento do teor das deliberações tomadas, caso não tenha sido convocado pela assembleia respectiva.

Portanto, salvo melhor juízo, uma vez demonstrada a plausibilidade do direito a partir de possíveis violações das deliberações tomadas aos estatutos ou contratos sociais, o periculum in mora passa a ser presumido se a demanda cautelar for proposta dentro do prazo de dez dias mencionado no art. 380, 1, do CPC português.

$\mathrm{O}$ art. 381, 2, do Código, expressamente, prevê a existência de dano inverso como requisito para o não deferimento da suspensão, ou seja, constatado pelo juiz ou tribunal que o risco de suspensão é, proporcionalmente, maior do que o risco da execução, a cautelar será indeferida, ainda que as deliberações sejam contrárias à lei, aos estatutos e aos contratos

\footnotetext{
${ }^{12}$ O Código Civil português, a propósito, faz menção expressa ao prazo de 01 ano no seu art. 1.278, 2, ao dispor que No caso de recorrer ao tribunal, o possuidor perturbado ou esbulhado será mantido ou restituído enquanto não for convencido na questão da titularidade do direito.
} 
sociais. Em nosso entendimento, a disposição supra deve ser apreciada em conformidade com a função social da empresa e das associações sem fins lucrativos, num juízo de ponderação, pois do contrário, seria difícil sustentar que uma deliberação violadora da legislação em vigor, por exemplo, devesse ser executada mesmo que um dos sócios requeresse no prazo legal a sua suspensão.

As disposições que regem as cautelares de suspensão das deliberações sociais são aplicáveis, no que couber, às medidas de suspensão das deliberações de assembleias condominiais, que, por este prisma, podem ser suspensas desde que qualquer condômino proponha a demanda acautelatória no prazo legal de dez dias e a plausibilidade do direito seja demonstrada a partir da demonstração de que a deliberação assemblear violou a lei, o regimento interno ou a convenção condominial.

\subsection{Alimentos provisórios}

A tutela cautelar de alimentos é satisfativa, ajustada na categoria proposta de antecipação de efeitos jurídicos, e destina-se a fixar alimentos provisoriamente ao alimentando até que sejam fixados em caráter definitivo na tutela final, que será concedida na sentença a ser prolatada na demanda principal.

O CPC português, quanto a esta espécie de cautelar, estimulou a composição amigável como forma, inclusive, de dispensar a propositura da ação principal. Assim, realizado o juízo de admissibilidade positivo da ação cautelar e, eventualmente, fixados os alimentos liminarmente, o réu é citado para uma audiência com o objetivo de conciliar as partes, e, uma vez transigindo as partes, não haverá necessidade de ajuizamento de uma ação principal, já que a composição homologada prestar-se-á à resolução do litígio pela via conciliatória.

Neste mesmo ato, deverá o réu apresentar contestação para a hipótese de não ser obtida a conciliação. A rigor, parece-nos que, a despeito da semelhança procedimental com o modelo brasileiro previsto no Capítulo $\mathrm{X}$ do título III, o sistema brasileiro tem a vantagem de ser designada uma audiência apenas para mediação ou conciliação, sem a necessidade de ser, desde logo, apresentada a contestação. Os advogados assim, podem concentrar-se nas proposições para uma composição amigável ao invés de despender labor e energia para 
elaboração da peça contestatória que, eventualmente, será prescindível diante da perspectiva de um acordo.

O sistema processual português prevê, ademais, que a revisão dos alimentos não importará em novo ajuizamento de demanda com esta finalidade, devendo o pleito revisional, para majorar ou reduzir o valor dos alimentos fixados, ser deduzido nos próprios autos originários, que, supomos, será desarquivado para este propósito.

\subsection{Arbitramento de reparação provisória}

A cautelar de arbitramento de reparação provisória, de caráter funcional satisfativo, presta-se à fixação de um valor indenizatório transitório à vítima de um evento de lesão corporal ou às pessoas que dela dependiam, no caso do fato danoso ter resultado em morte. Neste último caso, a cautelar pode ser proposta pelo cônjuge e herdeiros da vítima, e, bem assim, por aqueles a quem a vítima prestava alimentos a título de cumprimento de obrigação natural, como seria a hipótese, por ilustração, da vítima que prestava alimentos ao tio ou ao sobrinho ou mesmo à pessoa que lhe dedicou cuidados na sua infância.

E de fato, o CPC luso faz remissão expressa ao art. 495, 3 do Código Civil, que estabelece, por seu turno, os terceiros atingidos reflexamente pelos danos que resultaram na morte da vítima e que, por conta disso, estão legitimadas a pleitear a indenização e a proporem a cautelar de reparação provisória. Para que seja deferida a medida liminar, mesmo sem o exercício do contraditório, já que a cautelar em tela tem natureza alimentar, é indispensável que sejam comprovados os requisitos genéricos para o deferimento de uma tutela cautelar, ou seja, a plausibilidade do direito e o periculum in mora.

Não basta, como parece evidente, que o autor apresente apenas a prova do resultado danoso. É imprescindível, nesta senda, que seja apresentada prova documental ou documentada indicativa da probabilidade do seu direito, vale dizer, o dano em si e a perspectiva, mesmo em cognição superficial, de que o nexo causal está presente e está interligado à atuação do réu. ${ }^{13}$

13 Neste sentido, Acórdão n. 1250/16.3T80ER.L1-1, do Tribunal da Relação de Lisboa. Fonte: http://www.dgsi.pt/jtrl.nsf/-/66930781DEDAB27980258089005317C0, acesso em 06/12/2019. 
O periculum in mora, por sua vez, deve estar presente a partir da comprovação da situação de necessidade econômica dos autores. Parece óbvio, por este vértice, que se as pessoas que, num primeiro momento, recebiam valores mensais da vítima do óbito e depois passaram a exercer atividade laborativa remunerada que lhes assegurem a própria subsistência ou alteraram a sua condição econômica, o requisito em apreço não se faria presente para fins de concessão da tutela cautelar de arbitramento de reparação provisória.

A indenização fixada na cautelar deverá ser liquidada por equidade, especialmente nos casos em que não for possível aquilatá-la com maior precisão. Assim, se a vítima percebia mensalmente valores fixos, a tarefa da liquidação provisória para fins de arbitramento cautelar do quantum indenizatório será pautada em subsídios mais palpáveis. De todo o modo, o valor da indenização que foi objeto de liquidação provisória deverá ser imputado na liquidação definitiva do importe indenizatório a ser fixado na sentença que será prolatada na ação principal.

E, se porventura, a medida cautelar incorrer em caducidade ou a pretensão indenizatória deduzida na ação principal for julgada improcedente, impõe-se ao autor a obrigação de restituir os valores que recebeu provisoriamente. Apesar do tema suscitar debates para sua melhor delimitação, prevalece na jurisprudência brasileira a tese que sustenta a irrepetibilidade das verbas alimentares, o que torna a previsão do CPC português sem precedente no sistema brasileiro. ${ }^{14}$

\subsection{Arresto}

O arresto é uma medida cautelar vocacionada à conservação de direitos ou, mais precisamente, à garantia de direitos, destacadamente, o direito de um crédito que será discutido numa demanda principal e que poderá vir a perecer caso não seja deferida a tutela acautelatória a tempo para assegurar a futura execução por quantia certa.

Como medida assecuratória, o arresto previne o pericolo di frutuositá que, em breve síntese, representa o risco de que o direito não seja realizado num momento posterior em face da postura do requerido, o qual, por sua vez, visando frustrar a execução que poderá vir

\footnotetext{
${ }^{14}$ Como exemplo, mencionamos o teor Súmula 621 do STJ: Os efeitos da sentença que reduz, majora ou exonera o alimentante do pagamento retroagem à data da citação, vedadas a compensação e a repetibilidade.
} 
a ocorrer, dissipa o seu patrimônio durante o trâmite da ação principal. Trata-se, portanto, de uma medida que presta cautela à futura execução pecuniária e impede a sua frustação em virtude de atitudes desleais do réu com o objetivo de ocultar ou dilapidar o seu patrimônio.

A medida de arresto exige os mesmos requisitos para a concessão das tutelas cautelares. Assim, a probabilidade do direito equivale à perspectiva verossímil da existência do crédito, ao passo que o periculum in mora é representado pelos indícios de dissipação do patrimônio que asseguraria o recebimento do crédito futuro.

O Código de Processo Civil brasileiro em vigor suprimiu o livro das cautelares que era previsto no Código revogado. Com isto, simplificou-se o regime das tutelas cautelares, notadamente porque caberá à parte requerer - e ao juiz eleger - a medida mais adequada para a salvaguarda do direito material posto em juízo, que reclama uma providência conservativa.

No CPC/73, a propósito, a cautelar de arresto era organizada em capítulo específico, que exigia a presença de situações objetivas como requisitos para a sua concessão. Assim, os pressupostos do arresto eram impostos de acordo com a circunstância do devedor ter, ou não, domicílio certo. Também estabelecia para a comprovação do fumus boni iuris a prova literal de uma obrigação líquida e certa em face do devedor, o que, a priori, afastava a possibilidade de ser deferido o arresto diante de um crédito latente, porém dotado de elevada probabilidade, como seria o exemplo de uma sentença condenatória em quantia certa ainda pendente de análise recursal.

O CPC lusitano, por seu turno, autoriza a concessão do arresto mediante a previsão normativa de uma cláusula aberta pertinente ao periculum in mora, a qual contenta-se com o receio de o credor ter frustrada sua garantia patrimonial. Quanto ao fumus boni iuris, o CPC luso conferiu amparo a um crédito que ainda não restou constituído definitivamente, o que se coaduna com a ideia de mera probabilidade de um direito de crédito para que seja deferida a medida. Essa possibilidade, ao menos sob a égide do CPC/73, não era admissível, porquanto a exigência expressa da prova literal de dívida líquida e certa não era compatível com uma interpretação extensiva que assegurasse o arresto cautelar em face de créditos prováveis, ao contrário do que ocorre com o art. 392, 1 do CPC português. ${ }^{15}$

\footnotetext{
${ }^{15}$ Artigo 392.
} 
O arresto opera-se através de apreensão judicial de bens, observando-se as regras da penhora no que não for incompatível. À evidência, em se tratando de bens imóveis, embora o CPC português não seja explícito, o arresto perfaz-se mediante a anotação no título de propriedade do imóvel. A tutela cautelar de arresto é uma das exceções previstas nas cautelares do sistema português quanto à exigência de contraditório prévio, de modo que a sua concessão, uma vez presentes os requisitos supramencionados, é realizada sem a oitiva da parte contrária.

Esta regra, a nosso aviso, encontra justificativa na possibilidade de o requerido lançar mão de manobras com o objetivo de dificultar o cumprimento da tutela cautelar de arresto caso tenha ciência de sua decretação.

O CPC português prevê um regime especial de caducidade, sem prejuízo das hipóteses gerais previstas. Assim, opera-se a caducidade se, transitada em julgado a sentença na ação principal, o credor não iniciar o seu cumprimento no prazo de dois meses ou, da mesma forma, se não promover as diligências que lhe cabem no prazo de trinta dias.

Por fim, destacamos que o art. 396, n. 3, do CPC, dispensa a comprovação da plausibilidade do direito para fins de concessão do arresto se o bem em que incidirá a medida houver sido adquirido mediante negócio jurídico inadimplido total ou parcialmente pelo réu. Esta hipótese tem aplicação para os contratos de compra e venda e, ao que parece, para os ajustes obrigacionais gravados com ônus real, como é o caso da alienação fiduciária.

\subsection{Embargo de obra nova}

O embargo de obra nova, tutela cautelar de regulação provisória de uma situação jurídica, de acordo com o modelo português, é voltado a resguardar o direito de propriedade, direitos reais e o exercício da posse do titular do imóvel que é confrontado com obras em curso que possam causar-lhe prejuízo quanto à sua utilização e destinação. Enfim, esta medida cautelar tem por escopo a prevenção de danos que podem ser causados às edificações

1 - O requerente do arresto deduz os factos que tornam provável a existência do crédito e justificam o receio invocado, relacionando os bens que devem ser apreendidos, com todas as indicações necessárias à realização da diligência. 
por conta de obras novas e funda-se no direito de vizinhança e na observância das normas construtivas previstas em regulamentos administrativos.

No sistema brasileiro, sob a égide do Código revogado, era previsto medida similar no rol dos procedimentos especiais, com a denominação de nunciação de obra nova e que tinha as mesmas características gerais contempladas no CPC luso. No Brasil, a sua revogação como procedimento especial não afasta, por óbvio, a possibilidade do titular de um direito requerer a tutela satisfativa com teor inibitório, para impedir que o seu direito de vizinhança seja violado pelo início de uma obra irregular, devendo adotar-se o procedimento comum em tal situação.

O processo civil português assemelha-se, portanto, ao procedimento especial que era estabelecido no CPC/73, e prevê, inclusive, a possibilidade de o embargo ser realizado pela via extrajudicial, mediante notificação verbal na presença de duas testemunhas do responsável pela obra para que ela seja suspensa imediatamente, seguindo-se o ajuizamento da demanda judicial pelo titular do direito real violado no prazo de cinco dias. Esta previsão aplica-se para os casos em que o risco causado ao autor pelo prosseguimento da obra é de tal proporção que não comporta a espera de uma decisão judicial e o seu cumprimento.

É importante observar que o Estado e as demais entidades públicas, estão autorizadas a realizar o embargo de obras privadas, embora desprovidas de competência administrativa para tanto, se as obras em curso estiverem em desacordo com leis e regulamentos de posturas construtivas.

No tocante às obras públicas, porém, aí incluídas as executadas por concessionárias de serviços públicos, o embargo depende da provocação do contencioso administrativo. Deve ser ressaltado, todavia, que, uma vez constatado o perigo iminente decorrente da execução de obra pública prestes a causar danos ao titular do direito real ou possuidor, nada impediria que o embargo extrajudicial previsto no art. 397, n.2 do CPC fosse levado adiante, o que decorre de uma interpretação teleológica do dispositivo em apreço.

\subsection{Arrolamento}


O arrolamento de bens, por seu turno, é uma cautelar que tem por finalidade o resguardo de bens, sejam móveis ou imóveis, assim como de documentos de conteúdo econômico, nas hipóteses em que esteja presente o risco de extravio, ocultação ou dissipação.

A primeira observação que se faz, é a proximidade do arrolamento com a então medida cautelar de sequestro prevista no CPC brasileiro de 1973, a qual se destinava, em breve síntese, à proteção de um bem individualizado que estivesse sob litígio, o que ocorria através de sua apreensão e depósito público em geral. No CPC português, a propósito, não há a previsão do sequestro como medida cautelar.

Uma outra observação importante refere-se à circunstância de que o arrolamento, tal como previsto no atual CPC português e de acordo com o CPC/73, que buscou inspiração no então vigente Código lusitano de 1961, teve seu espectro de incidência ampliado para além das situações envolvendo partilha no direito de família.

Portanto, em conformidade com o sistema português, a cautelar de arrolamento presta-se a conservar bens de apreciação econômica, inclusive documentos com esta característica, como títulos de crédito e demais contratos que reconheçam a existência de uma obrigação a ser adimplida, tudo para prevenir o seu perecimento, enquanto se discute numa demanda principal a sua partilha ( que, inclusive, pode ocorrer fora das hipóteses do direito de família, como nas ações de dissolução de sociedades) ou a sua titularidade.

\section{As cautelares atípicas e as suas linhas gerais}

O sistema processual luso convive com as tutelas cautelares típicas e atípicas, ou, consoante está disposto no Capítulo I do Título IV do CPC, cautelares não especificadas, o que, de certa forma, correspondia ao modelo adotado pelo CPC brasileiro de 1973, com algumas nuances.

Assim, conforme já referido, o CPC português não admite que as tutelas cautelares atípicas sejam utilizadas como sucedâneo das cautelares típicas ou especificadas, o que equivale a dizer que, não reunidos os requisitos para a concessão de uma tutela cautelar especificada, não poderá o autor valer-se das tutelas atípicas para obter um resultado similar. 
As cautelares atípicas, por outra via, exigem como requisitos para a sua concessão a plausibilidade do direito e o periculum in mora, o que, a rigor, correspondem aos pressupostos para o deferimento de qualquer espécie de medida.

A tutela cautelar, no mais, assume em linhas gerais, funções conservativas ou antecipatórias dos efeitos do mérito, ainda que seja adotada a classificação proposta pela doutrina lusitana quanto às três categorias já mencionados neste ensaio, quais sejam: garantia de um direito, regulação provisória de situação jurídica e antecipação de efeitos jurídicos ou da tutela definitiva. Isto porque, a tutela cautelar voltada à regulação provisória de uma situação jurídica, a despeito de cumprir esta finalidade, não deixa de ostentar um caráter antecipatório, o que pode ser verificado por ilustração, na decisão que concede a tutela de restituição provisória na posse que coincide, a rigor, com o objeto da tutela final.

O contraditório no procedimento cautelar é a regra que deve ser observada, apesar de comportar exceções nos casos em que o seu exercício puder comprometer a eficácia da medida, hipótese em que será dispensado. Uma peculiaridade que, sob nossa perspectiva, aproxima bastante os sistemas brasileiro e português: Trata-se do poder geral de cautela, que, assim como previsto expressamente no CPC brasileiro, encontra um dispositivo correspondente no art. 361,1, do Código luso, o qual assegura às partes requerer a providência cautelar adequada à tutela de seus direitos.

Este dispositivo deve ser interpretado em conjunto com a disposição inserta no art. 376, 3, primeira parte, do Estatuto Português, que desvincula o juiz ou tribunal da cautelar solicitada, ou seja, permite que eles amoldem a medida de urgência da forma mais apta a tutelar o direito das partes. ${ }^{16}$

\section{A inversão do contencioso e o rompimento do dogma da instrumentalidade}

A tutela cautelar apresenta como uma das suas características essenciais a instrumentalidade, matizada pela sua vocação de prestar-se como mecanismo apto à preservação do direito material, e, mais precisamente, do direito que será discutido na

\footnotetext{
${ }^{16}$ Abrantes Geraldes, ao comentar disposição idêntica introduzida numa das reformas anteriores à vigência do CPC português, destacou: A referida norma comporta, de modo que nos parece claro, uma "excepção ao princípio do dispositivo", atribuindo ao juiz poderes para determinar a medida cautelar que considere mais adequada à tutela dos interesses (...) GERALDES, A. S. A. Tema da Reforma do Processo Civil - Princípios Fundamentais - Fase Inicial Do Processo Declarativo. Coimbra: Almedina, 1997.
} 
demanda ou, no caso português, na ação principal, já que o sistema luso ainda mantém a autonomia estrutural da ação cautelar que é processada em autos próprios.

Tal característica, a propósito, conforme doutrina de Piero Calamandrei, revela-se como uma instrumentalidade qualificada, a partir da premissa de que, se o processo em si, é um instrumento a serviço do direito material que será, porventura, declarado na tutela definitiva prestada na sentença de mérito, a tutela cautelar apresenta-se como um instrumento desse mecanismo de prestação jurisdicional e certificação de direitos, daí, portanto, a denominação consagrada pelo mestre fiorentino de que a tutela cautelar é um instrumento do instrumento ou que se reveste de uma instrumentalidade qualificada ou hipotética $^{17}$.

E se é correto afirmar que a instrumentalidade permanece hígida como característica marcante das tutelas cautelares, diante da sua função de assegurar a eficácia do direito substancial até que ele seja realizado faticamente, no sistema português, um novo regime aplicável às cautelares parece ter como consequência, justamente, a ruptura desta relação instrumental diante da possibilidade de converter uma tutela acautelatória em definitiva. ${ }^{18}$

Trata-se do regime da inversão do contencioso introduzido pelo CPC lusitano em vigor desde o ano de 2013. O formato procedimental de tal regime autoriza que, mediante pedido do autor e atendidos determinados requisitos, o juiz, ao reconhecer a aplicação do regime em apreço, dispense o autor do ônus de aforar a demanda principal e atribua este ônus ao réu, a quem incumbirá o seu ajuizamento no prazo de trinta dias contados do trânsito em julgado da decisão que decretou o regime de inversão do contencioso, o que se assemelha, a nosso juízo, às premissas da técnica monitória que impõe a inversão do ônus de propor a demanda em cognição exauriente.

A técnica adotada no sistema português, dessa forma, mostra-se peculiar, em primeiro plano, por afastar o dogma da instrumentalidade da tutela cautelar em relação à tutela definitiva, na medida em que autoriza a conversão da tutela deferida em uma ação cautelar num provimento definitivo e apto à composição da controvérsia que seria instaurada

17 CALAMANDREI, P. Introduzione allo studio sistematico dei provvedimenti cautelari, Opere Giuridiche. v. IX. Padova: CEDAM, 1936.

${ }^{18}$ Quanto à relação de instrumentalidade, o próprio CPC luso é expresso, ao dispor, no seu art. 364, 1, que Exceto se for decretada a inversão do contencioso, o procedimento cautelar é dependência de uma causa que tenha por fundamento o direito acautelado e pode ser instaurado como preliminar ou como incidente de ação declarativa ou executiva. grifamos 
na demanda principal. Em última análise, o provimento cautelar é convolado numa tutela definitiva, desde que, decretado o regime e operado o trânsito em julgado da decisão respectiva, o réu não apresente uma ação principal proposta com a finalidade de discutir a própria existência do direito acautelado.

Para que o juiz possa decretar o regime de inversão do contencioso, além de ser imprescindível o requerimento expresso do autor, ele deve formar a sua convicção segura quanto à existência do direito objeto da cautela e, além disso, constatar que a tutela cautelar concedida é suficiente para resolver o litígio em caráter definitivo.

A convicção segura que, em princípio, poderia sugerir a mera probabilidade da existência do direito acautelado, parece ter um sentido mais intenso do que a prova que, numa cognição sumária, permite a concessão da tutela cautelar em virtude de o juiz formar a sua convicção a partir de verossimilhança. Por este prisma, não basta a prova produzida pelo autor que é indicativa de que o direito acautelado está cercado de grande probabilidade de ser acolhido no momento de ser apreciada a tutela definitiva.

Ao que parece, a convicção segura deve ser formada a partir de uma prova que, uma vez apresentada nos autos, permita ao juiz na sua valoração, convencer-se a respeito da existência do direito acautelado independente da produção de outras modalidades probatórias, que, no caso, seriam até desnecessárias.

Embora o conceito ora apresentado seja coerente com um juízo de certeza, o que, de certo modo, contradiz com o juízo de probabilidade exigido para as cautelares, não vislumbramos outra possibilidade de o juiz decretar um regime que resultará na dispensa do autor propor a ação principal e, eventualmente, convolar uma tutela cautelar em definitiva, sem que esteja respaldado numa prova que lhe assegure a formação de seu convencimento a partir de um elemento mais robusto do que a mera probabilidade da existência do direito acautelado. $^{19}$

\footnotetext{
${ }^{19}$ Miguel Teixeira de Souza, neste sentido, sustenta que: O juiz tem de formar a convicção segura da existência do direito acautelado, o que implica que a prova sumária (ou seja, a prova que se basta com a probabilidade séria da existência do direito acautelado) que é suficiente para decretar a providência cautelar (cf.art. $365^{\circ}, \mathrm{n}^{\circ} 1$, $388^{\circ}, \mathrm{n}^{\circ} 2,392^{\circ}, \mathrm{n}^{\circ} 2$, e $405^{\circ}, \mathrm{n}^{\circ} 1$ ) é insuficiente para decretar a inversão do contencioso; esta inversão pressupõe uma prova stricto sensu do direito acautelado; portanto, o que conta é que o juiz forme a conviç̧ão segura da existência do direito que a providência se destina a acautelar, não a conviçção segura da procedência da providência; (TEIXEIRA DE SOUSA, M. As providências cautelares e a inversão do contencioso. 2013. Disponível

em: https://www.academia.edu/5973963/TEIXEIRA_DE_SOUSA_M._As_provid\%C3\%AAncias_cautelares_e_ a_invers\%C3\%A3o_do_contencioso_12.2013_?auto=download. Acesso em: 27/112019).
} 
E, certamente, haverá situações em que o acervo de provas apresentado numa ação cautelar será satisfatório para o juiz convencer-se a respeito da existência de um direito acautelado, o que dispensaria a produção probatória oportuna e permitiria, dessa forma, a aplicação do regime da inversão do contencioso em comento.

Poderíamos pensar, assim, numa tutela cautelar antecipatória com conteúdo inibitório, na qual a demonstração da ilicitude que se pretende evitar e que seja simétrica com o pedido de tutela final, possa ser aferida, prontamente, a partir de prova documental ou documentada escrita (ata notarial, por exemplo) que prescinda de uma instrução probatória posterior.

Evidentemente, apenas as cautelares satisfativas do direito português estão albergadas pela hipótese de adoção do regime de inversão do contencioso, o que é repisado pela expressa disposição inserta no art. 376, n.4 do CPC, a qual, no tocante às tutelas especificadas ou típicas, estabelece que o regime é observado apenas quanto às cautelares de restituição provisória da posse, suspensão de deliberações sociais, aos alimentos provisórios e embargo de obra nova.

Esta previsão contida no CPC lusitano confirma, a nosso sentir, o fundamento de que as tutelas cautelares que se enquadram na categoria de regulação de uma situação provisória, como é o caso da restituição provisória da posse e embargo de obra nova, na verdade, melhor acomodam-se num perfil de tutelas satisfativas ou antecipatórias.

Também se admite o regime de inversão do contencioso nas demais tutelas cautelares satisfativas contempladas em legislação extravagante, do que é exemplo, consoante pontuou Miguel Teixeira de Sousa, a cautelar de entrega judicial pós término do contrato de locação financeira, regido pelo Decreto-Lei n. $149 / 95 .^{20}$

As cautelares típicas de arbitramento de reparação provisória, a priori, foram excluídas do regime de inversão do contencioso apesar do seu inegável caráter satisfativo. Ao que parece, esta exclusão está fundada no procedimento da medida cautelar em voga, cujo art. $388^{\circ}, 2^{\circ}$, atribui ao juiz ou tribunal o mister de liquidar provisoriamente o dano por apreciação equitativa. Assim, malgrado a providência cautelar seja simétrica ao pedido de tutela final, a eventual impossibilidade de aquilatar o valor integral do quantum indenizatório

\footnotetext{
${ }^{20}$ TEIXEIRA DE SOUSA, M. idem supra.
} 
de plano, impede a aplicação do regime, diante da necessidade de ser realizada oportuna liquidação para fixação do valor indenizatório final.

Pensamos, todavia, que, uma vez possível aferir a extensão do dano sem a necessidade de uma liquidação futura e, desde que as provas apresentadas sejam suficientes para concluir pela existência do direito acautelado (imagine-se uma colisão traseira de veículos que tenha resultado na incapacidade da vítima de laborar por um prazo de tempo curto e definido), não haveria óbice a que o regime de inversão do contencioso fosse observado, se a providência cautelar satisfativa tiver o condão de compor o litígio em caráter definitivo.

Aliás, é bom que seja mencionado que o segundo requisito para que o regime de inversão do contencioso possa ser decretado pelo juiz - além da convicção segura da existência do direito -, é, justamente, a aptidão da tutela cautelar satisfativa em resolver definitivamente o litígio. E, conforme é intuitivo, tal somente pode ocorrer em relação às tutelas cautelares satisfativas ou antecipatórias, nestas abrangidas as cautelares que se ajustam na categoria de regulação provisória de uma situação jurídica (restituição provisória da posse e embargo de obra nova).

Neste caso, parece óbvio que as tutelas cautelares conservativas, pela sua própria funcionalidade, não têm aptidão para colocar um termo ao litígio em definitivo, já que se prestam a, essencialmente, resguardar a execução futura e evitar o perecimento do direito reconhecido na tutela final.

Assim, não caberia a aplicação do regime de inversão do contencioso, por ilustração, num pedido de medida cautelar de arresto ou arrolamento de bens, já que tais providências, seguramente, não se coadunam com a resolução definitiva do litígio, eis que estão relacionadas com a conservação do direito substancial que pode sucumbir ao pericolo di frutuositá, na lição de Calamandrei.

Uma vez decretado o regime de inversão do contencioso - o que poderá ser realizado até a audiência final mediante requerimento do autor -, o réu poderá interpor recurso em face da decisão concessiva do regime. Inclusive, se a medida cautelar for deferida sem o contraditório e, nessa mesma decisão o juiz decretar o regime, o recurso a ser interposto pelo réu poderá ser único e abranger a sua irresignação em face da liminar concedida e da decretação do regime. 
O prazo para a propositura da ação principal, que é de trinta dias contados da decisão que conceder a medida cautelar, interrompe-se com o pedido de inversão do contencioso, reiniciando-se a sua contagem a partir do trânsito em julgado da decisão que indeferir o regime. Em suma, enquanto estiver pendente a análise do pedido e, bem assim, a decretação do regime em caráter definitivo, não há que se falar em caducidade pela ausência de ajuizamento da demanda principal.

Dessa forma, com o trânsito em julgado da decisão que não decreta a inversão do contencioso, o que poderá ocorrer em primeiro grau se, desde logo, o juiz indeferir o regime, já que esta decisão é irrecorrível, ou no âmbito recursal, se a decisão concessiva do regime foi reformada pelo tribunal, inicia-se o prazo para o autor ajuizar a ação principal.

Outra situação ocorre se houver a decretação do regime de inversão do contencioso e a decisão respectiva transitar em julgado. Neste caso, em virtude de operar-se a inversão do ônus de propor a ação de cognição exauriente, cumpre ao réu ajuizar a demanda respectiva no prazo de trinta dias contados da sua intimação a respeito. Esta é dicção contida no art. 371, 1, do CPC luso. Do contrário, a decisão deferida no bojo da ação cautelar em que foi decretada a inversão do contencioso prestar-se-á para a resolução definitiva do litígio, vale dizer, para reconhecer a existência do direito acautelado com as suas repercussões e eficácias decorrentes.

Assim, se, por exemplo, for concedida a restituição provisória da posse de um imóvel na ação cautelar e decretado o regime de inversão do contencioso, o trânsito em julgado desta decisão e o decurso do prazo para o ajuizamento da ação de cognição exauriente pelo réu importará na composição definitiva do litígio, e, por consequência, a posse será restabelecida em favor do autor sem que a matéria possa ser rediscutida, diante da formação da coisa julgada material ou caso julgado, conforme terminologia utilizada no processo civil português. $^{21}$

\section{Tutelas autossatisfativas e tutelas de urgência stricto sensu}

\footnotetext{
${ }^{21}$ De acordo com José Lebre de Freitas: "Entre nós, passado o prazo de 30 dias concedido ao requerido para a propositura da ação principal sem que esta seja proposta, a providência decretada converte-se em decisão definitiva do litígio, mudando assim de natureza e, embora a lei evite dizê-lo, ganhando a eficácia própria do caso julgado material." (SILVA, J. C. et al. (Orgs.). A Inversão do Contencioso nos Procedimentos Cautelares. Processo Civil Comparado — Análise entre Brasil e Portugal. 1. ed. São Paulo: Forense, 2017).
} 
A tutela autossatisfativa, em breve síntese, associa-se a uma tutela diferenciada que foi desenvolvida sobretudo no direito argentino pela doutrina do Prof. Jorge Peyrano e que apresenta as seguintes características essenciais: i- a urgência do requerimento; ii- a elevada probabilidade quanto à existência do direito; iii- a capacidade de exaurimento da pretensão do autor, com a mera decretação da medida, o que dispensa o ajuizamento de uma ação principal para evitar a caducidade. ${ }^{22}$

As tutelas autossatisfativas, portanto, não seguem a lógica de uma relação instrumental com uma demanda posterior, conforme ocorre no caso das ações cautelares, e tampouco dependem, a rigor, de uma cognição aprofundada ou lastreada em ampla produção probatória para que a resolução do conflito seja realizada.

O sistema português contempla uma técnica processual representada por uma tutela cautelar autônoma que se ajusta perfeitamente ao conceito de tutela autossatisfativa. Referimo-nos às tutelas de urgência stricto sensu, que se destinam à proteção dos direitos da personalidade e diferem das tutelas cautelares do direito luso em virtude de possibilitarem a outorga de uma prestação definitiva com a sua concessão, através de um procedimento simplificado. $^{23}$

Assim, de acordo com a exegese extraída dos arts.878 a 880 do Código de Processo Civil, as tutelas de urgência stricto sensu visam tutelar os direitos da personalidade do indivíduo que se encontram na iminência de serem violados, prestando-se da mesma forma, para fazer cessar os efeitos de uma ofensa já perpetrada. Esta tutela de urgência, portanto, reveste-se de conteúdo inibitório e assume uma função autossatisfativa a partir de um provimento executivo voltado a combater um ilícito futuro ou remover um ilícito já exaurido, mas cujos efeitos perduram-se ao longo do tempo.

Trata-se, assim, de uma tutela de urgência autônoma direcionada principalmente contra o ilícito prestes a violar um direito da personalidade, como seria o exemplo da

\footnotetext{
${ }^{22}$ PEYRANO, W. J. Medidas autosatisfactivas. Buenos Aires: Rubizal; Culzoni, 1997.

${ }^{23}$ Miguel Teixeira de Sousa esclarece que: A distinção resume-se no seguinte: a tutela cautelar é uma tutela provisória ou uma tutela que só se consolida se, tendo havido inversão do contencioso, o requerido não propuser ação destinada a contrariar a providência decretada; a tutela urgente stricto sensu é uma tutela definitiva que é obtida num procedimento simples e célere. TEIXEIRA DE SOUSA, M. As providências cautelares e a inversão do contencioso. $2013 . \quad$ Disponível em: https://www.academia.edu/5973963/TEIXEIRA_DE_SOUZA_M._As_provid\%C3\%AAncias_cautelares_e_ a_invers\%C3\%A3o_do_contencioso_12.2013_?auto=download. Acesso em: 27/11/2019.
} 
propagação de notícia difamante em redes sociais. A tutela de urgência stricto sensu por esta ótica, atua antes que um dano possa ser concretizado, e, uma vez deferida, o seu objeto estará exaurido, razão pela qual, a comparação com as tutelas autossatisfativas do direito argentino é absolutamente pertinente.

\section{Considerações Finais}

O tema tutelas provisórias ainda suscita muitas reflexões. No sistema processual brasileiro, o recente Código de Processo Civil apresentou alterações significativas, como é o caso da extinção das tutelas cautelares típicas e a inserção das tutelas de urgência num único dispositivo, o que, certamente, contribuiu com a sua simplificação procedimental.

E, nada obstante persistir o debate a respeito do aspecto funcional das tutelas de urgência em face da distinção entre tutelas satisfativas e conservatórias, ao menos sob o prisma prático, esta diferenciação não compromete a operabilidade das tutelas sumárias fundadas na urgência, na medida em que o princípio da fungibilidade expressamente consagrado no CPC - como aliás, já era previsto no Código revogado - encarregou-se de equacionar qualquer repercussão prática que poderia ocorrer na hipótese de uma tutela com enfoque conservativo ser requerida como tutela antecipada e vice-versa.

As tutelas antecipadas antecedentes, por seu turno, surgiram como uma inovação destinada a assegurar a efetividade das tutelas de urgência atrelada a um regime de estabilidade que, a nosso sentir, ainda merece maior aprofundamento, sobretudo após o decurso do prazo de dois anos em que se opera a estabilização da tutela antecipada. A doutrina parece ter se posicionado amplamente no sentido de rechaçar a coisa julgada como estabilidade, o que, no entanto, não pode ser considerado como algo consolidado e imune a outros debates para o desenvolvimento da técnica inspirada no direito francês e italiano.

De resto, embora a utilização da tutela antecipada em caráter antecedente ainda não seja tão difundida, é importante destacar que o CPC ainda é muito recente e, portanto, o instituto poderá ser aperfeiçoado doutrinariamente e melhor compreendido pelos operadores do direito como uma técnica que pode ser muito eficaz para a resolução de algumas espécies de litígios, notadamente os que envolvem tutelas preventivas e repressivas em face do ilícito, 
com a vantagem de assegurar uma estabilidade após o decurso de um prazo relativamente exíguo.

O direito comparado, sem dúvida, é salutar para que boas experiências hauridas em outros sistemas jurídicos possam ser observadas e transpostas para o sistema pátrio, no que forem compatíveis, contribuindo assim, para o aperfeiçoamento das técnicas processuais locais. Esta premissa, por si, justifica a realização de estudos de temas processuais relacionados ao processo civil alienígena com este propósito, sem descuidar da interessante experiência de conhecer a cultura processual a partir de um outro prisma jurídico.

As tutelas de urgência no sistema português, representam, nesta linha de raciocínio, um tema bastante promissor para esta finalidade. Primeiro, é possível identificar a matriz doutrinária que também influenciou o nosso sistema, qual seja, as ideias desenvolvidas por Calamandrei. Portugal, no entanto, manteve-se fiel à classificação das tutelas satisfativas como tutelas cautelares, ao contrário do sistema brasileiro que, há muito tempo, estabeleceu a autonomia das tutelas satisfativas como uma categoria autônoma e diversa dentro do gênero tutela provisória de urgência, entendimento que prevalece na doutrina e que chancelou a tutela antecipada como funcionalmente distinta das tutelas cautelares que se prestam à segurança da execução, ou, como queira, à conservação de direitos.

No modelo português, a autonomia estrutural das cautelares, que permanecem sendo propostas em autos próprios que serão oportunamente apensados aos autos principais, não contribuiu com a simplificação procedimental e a economia processual já observadas no processo civil brasileiro, em que as tutelas provisórias são requeridas diretamente nos autos principais, seja pela via antecedente ou incidente. Isto, certamente, representou um avanço neste sentido, com o destaque para a situação das tutelas cautelares que, até a vigência da novel legislação ainda podiam ser aforadas em autos apartados, embora o princípio da fungibilidade inserido pela reforma do CPC brasileiro em 2002 passou a admitir que as cautelares pudessem ser requeridas nos autos principais, sem maiores divergências.

A convivência das tutelas especificadas com as tutelas atípicas do CPC luso encontra um regime similar ao que existia no sistema brasileiro sob a égide do Código de 1973. O sistema português optou por procedimentalizar, ao que parece, as cautelares típicas utilizadas com maior frequência pelos jurisdicionados. 
Todavia, entendemos que o modelo brasileiro ganha no aspecto da simplificação e efetividade, pois não é viável prefixar todas as situações de urgência que poderão reclamar a atuação da tutela cautelar, de modo que cumprirá ao autor apresentar a situação fática e elencar os requisitos que autorizam a concessão da tutela cautelar, independente de um procedimento prévio concebido apenas para determinadas espécies de cautelares, conforme observa-se no CPC lusitano.

O sistema português criou a inversão do contencioso no âmbito das cautelares, o que, a par de provocar uma ruptura com a instrumentalidade em relação à demanda principal, suscitou um debate interessante a respeito da possibilidade de convolação de um provimento realizado em cognição sumária numa tutela definitiva capaz de resolver o litígio. O regime merece um estudo mais aprofundado para as hipóteses de sua aplicação, inclusive no que tange à matéria que poderá ser discutida em eventual ação impugnativa proposta pelo réu (da ação cautelar), ao ônus probatório e à formação do caso julgado.

Não há como negar-se, todavia, que se trata de uma técnica muito interessante, que partiu de inspirações hauridas do direito francês e italiano, conforme ocorreu, aliás, com o nosso regime de estabilização da tutela antecipada, porém, mostrou-se mais ousado no sentido de, em princípio, assegurar que a estabilidade da decisão proferida em sede cautelar nos casos que comportam a aplicação do regime, opere-se pela imunização da coisa julgada material.

O direito comparado, assim, cumpre uma função relevantíssima a partir da premissa de que, a análise de temas correlatos emanados de diferentes sistemas processuais viabiliza um intercâmbio suscetível de, não apenas confrontar, mas, sobretudo, contribuir para aprimorar os institutos com fundamento nas experiências bem-sucedidas desenvolvidas em cada um dos sistemas que foram objeto dos estudos respectivos.

\section{REFERÊNCIAS:}

BONATO, G. A estabilização da tutela antecipada de urgência no Código de Processo Civil brasileiro de 2015 (uma comparação entre Brasil, França e Itália). Revista de Processo, São Paulo, v. 273, 2017. p. 191-253. 
BEDAQUE, J. R. Tutela Cautelar e Tutela Antecipada: Tutelas Sumárias e de Urgência (tentativa de sistematização). 5. ed. rev. e ampl. São Paulo: Malheiros, 2009.

BUENO, C. S. et al. (Coords.). Tutela Provisória no Novo CPC: dos 20 anos de vigência do art. 273 do CPC/1973 ao CPC/2015. São Paulo: Saraiva, 2016.

CALAMANDREI, P. Introduzione allo studio sistematico dei provvedimenti cautelari, Opere Giuridiche. v. IX. Padova: CEDAM, 1936.

CASTANHEIRA, J. M. C. As Providências Cautelares e os Requisitos para o seu Decretamento - Confronto entre o Processo Administrativo e Processo Civil. Dissertação (Mestrado em Direito Administrativo) - Faculdade de Direito, Universidade de Coimbra. Coimbra, Portugal, 2018. Disponível em: estudogeral.uc.pt/bitstream/10316/86628/1/Tese\%20Joana\%20Castanheira.pdf. Acesso em: 30/11/2019.

COSTA E SILVA, P. Cautela e certeza: breve apontamento acerca do proposto regime de inversão do contencioso na tutela cautelar. In: SINDICATO DOS MAGISTRADOS DO MINISTÉRIO PÚBLICO. A reforma do processo civil. Lisboa, 2012. p. 13949. Disponível em: https://www.fd.unl.pt/docentes_docs/ma/pcn_ma_25216.pdf. Acesso em: 19/102019.

CUNHA, A. A. M. Comentários ao Código de Processo Civil. São Paulo: Editora Revista dos Tribunais, 2001. v. 11.

DA SILVA, O. A. B. Curso de Processo Civil. 3. ed., rev. e atual. São Paulo: Editora Revista dos Tribunais, 2000. v. 3.

DINAMARCO, C. R. Nova Era do Processo Civil. 4. ed. São Paulo: Malheiros, 2013.

GERALDES, A. S. A. Tema da Reforma do Processo Civil - Princípios Fundamentais Fase Inicial Do Processo Declarativo. Coimbra: Almedina, 1997.

GONÇALVES, M. C. Providências Cautelares. 3. ed. Coimbra, Portugal: Almedina, 2017. LYNCE, R. Apreciação da proposta de inversão do contencioso cautelar apresentada pela Comissão de Reforma do Código de Processo Civil. In: Estudos em homenagem ao Prof. Doutor José Lebre de Freitas. 2013.v. 1. p. 1139-53.

MARINONI, L. G. A Antecipação da Tutela. 8. ed. São Paulo: Malheiros: 2004.

MARQUES, J. P. R. Alguns aspectos processuais da tutela da personalidade humana no novo Código de Processo Civil de 2013. 2013. Disponível em: 
http://www.cej.mj.pt/cej/recursos/ebooks/ProcessoCivil/Reforma_do_processo_civi 1.pdf. Acesso em: 10/102019.

PEIXOTO, R. (Coords.). Coletânea Novo CPC: doutrina selecionada. Salvador: Juspodivm, 2015.

PEYRANO, W. J. Medidas autosatisfactivas. Buenos Aires: Rubizal; Culzoni, 1997.

SICA, H. V. M. Doze problemas e onze soluções quanto à chamada "estabilização de tutela antecipada". In: FREIRE, A.; BARROS, L. B. M.; PEIXOTO, R. (Coords.). Coletânea Novo CPC: doutrina selecionada. Salvador: Juspodivm, 2015.

SILVA, J. C. et al. (Orgs.). A inversão do Contencioso nos Procedimentos Cautelares. Processo Civil Comparado - Análise entre Brasil e Portugal. 1. ed. São Paulo: Forense, 2017.

SILVA, O. A. B. Curso de Processo Civil: Processo Cautelar. 3. ed. São Paulo: 2000. v. 3. TEIXEIRA DE SOUSA, M. As providências cautelares e a inversão do contencioso. 2013. https://www.academia.edu/5973963/TEIXEIRA_DE_SOUZA_M._As_provid\%C3 \%AAncias_cautelares_e_a_invers\%C3\%A3o_do_contencioso_12.2013_?auto=do wnload. Acesso em: 27/11/2019. 